Jurnal Kejaora: Jurnal Kesehatan Jasmani dan Olah Raga

ISSN: 2541-5042 (Online)

ISSN: 2503-2976 (Print)

Volume 5 Nomor 1, Edisi April 2020

\title{
KETERAMPILAN BERMAIN TIM PUTRA BOLA BASKET SMP NEGERI 2 TRENGGALEK PADA EVENT SMA NEGERI 1 DURENAN CUP 2019
}

\author{
Anandika Rahanggi Wardanis ${ }^{1}$, Henri Gunawan Pratama ${ }^{2}$ \\ 'SMP IT Permata Umat Trenggalek \\ 2STKIP PGRI Trenggalek \\ Email: andikarahanggi@gmail.com ${ }^{1}$, henrigunawan92@gmail.com² \\ DOI: https://doi.org/10.36526/kejaora.v5i1.840
}

\begin{abstract}
ABSTRAK
Tujuan Penelitian ini secara umum dan khusus adalah untuk mengetahui statistik dan menganalisis pertandingan tim putra bola basket SMP Negeri 2 Trenggalek pada SMA Negeri 1 Durenan Cup 2019. Jenis penelitian ini adalah kuantitatif dimana menggunakan pendekatan statistik deskriptif kuantitatif dan metode penelitian ini bersifat analisis data pertandingan dari hasil observasi langsung ke lapangan dan dokumentasi. Dari hasil penelitian pertandingan dapat diketahui bahwa total FG 146 percobaan dan berhasil 31 masuk mencapai (21\%), untuk 2 points percobaan 113 dan berhasil 30 masuk mencapai (26\%), untuk 3 points 31 percobaan dan hanya berhasil 1 masuk mencapai (3\%), FT 24 percobaan dan berhasil 6 bola masuk mencapai (25\%), RB untuk OR 28 kali, DR 39 kali jadi total RB yang dilakukan 67 kali, untuk AST 31 kali, TO 45 kali, STL 35 kali, BLK 4 kali, PF 17 kali. Berdasarkan data yang diambil dapat dismipulkan mulai dari FG dengan kategori baik, FT dengan kategori kurang, RB dengan kategori baik, ST dengan kategori baik, TO dengan kategori baik, AST dengan kategori baik, dan FO dengan kategori baik, BLK dengan kategori baik. Dari 8 komponen tersebut dapat ditentukannya apa saja yang perlu diperbaiki dan dipertahankan oleh tim SMP Negeri 2 Trenggalek pada event berikutnya.
\end{abstract}

Kata Kunci: Keterampilan,Statistik, Pertandingan, Bola Basket, SMA Negeri 1 Durenan Cup 2019

\section{PENDAHULUAN}

Pada umumnya olahraga mempunyai peranan dalam kehidupan manusia yaitu untuk meningkatkan kesegaran jasmani, mental dan rohani, serta ditujukan untuk pembentukan watak dan kepribadian, disiplin dan sportifitas yang tinggi. Tetapi dalam olahraga prestasi tujuannya akan lebih khusus lagi yaitu untuk meraih prestasi puncak (Fitriasmara, 2017).

Dalam setiap cabang olahraga memerlukan kesiapan kondisi fisik dan penguasaan teknik yang tinggi, disamping itu faktor mental dan emosional sebagai bagian dari sistem faktor penentuan keberhasilan. Kondisi fisik yang prima memegang peranan penting, terutama dalam permainan bolabasket yang merupakan cabang olahraga yang dinamis dengan tingkat intensitas tinggi dalam melakukan gerakan-gerakan teknik dan taktik, baik dalam team bertahan maupun team penyerang (Pratama, 2017).
Keterampilan adalah kemahiran atau penguasaan suatu hal yang memerlukan gerak tubuh dan diperoleh melalui latihanlatihan (Hapsari, Pratiknyo, \& Hidayah, 2013). Seperti jenis olahraga lainnya, untuk dapat bermain bola basket setiap orang yang ingin menekuni olahraga tersebut, terlebih dahulu harus menguasai beberapa ketrampilan dasar dalam permainan bola basket seperti passing, dribble, dan shooting (Nurrochmah, 2009). Pada permainan bola basket, untuk mendapatkan gerakan efektif dan efisien perlu didasarkan pada penguasaan keterampilan teknik dasar yang baik. Ketrampilan Teknik dasar dalam permainan bola basket dapat dibagi menjadi enam, yaitu : 1) Teknik melempar dan menangkap, 2) Teknik menggiring bola, 3) Teknik menembak, 4) Teknik gerakan berporos, 5) Teknik tembakan Lay up, dan 6) Merayah (Sodikun, 1992).

Bola basket sendiri merupakan salah satu cabang olahraga bola besar. Bola basket 
Jurnal Kejaora: Jurnal Kesehatan Jasmani dan Olah Raga

ISSN: 2541-5042 (Online)

ISSN: 2503-2976 (Print)

Volume 5 Nomor 1, Edisi April 2020

ini dimainkan oleh 2 tim yang masing masing terdiri dari 5 pemain. Tujuan dari masing masing tim adalah untuk mencetak angka ke keranjang lawan dan berusaha mencegah tim lawan mencetak angka (FIBA, 2018). Bola basket selain digunakan dalam olahraga masyarakat yang menyukainya, basket ini sendiri juga dipertandingkan dalam berbagai event atau disebut juga olahraga prestasi. Olahraga bola basket penggemarnya yang berasal dari segala usia merasakan bahwa bolabasket adalah olahraga menyenangkan, kompetitif, mendidik, menghibur, dan menyehatkan (Ridjal, 2016).

Untuk memperoleh prestasi yang setinggi-tingginya, perlu adanya latihanlatihan yang menggunakan pendeketan ilmiah. Para pelatih umumnya memiliki data sebagai acuan untuk evaluasi dan meningkatkan prestasi atlet mereka. Upaya pembinaan dan ilmu pegetahuan teknologi (IPTEK) perlu terus menerus ditumbuh kembangkan sehingga peningkatan dan pencapaian prestasi olahraga bola basket baik tingkat nasional maupun internasional dapat lebih maju dan lebih membanggakan (Fitriasmara, 2017).

Bola basket telah menjadi salah satu cabang olahraga yang sangat digemari khususnya di Kabupaten Trenggalek. Dalam pengembangan bakat atlet-atlet di daerah ini ada berbagai event resmi yang diselenggarakan Persatuan Bola Basket Seluruh Indonesia PERBASI Kabupaten Trenggalek, salah satunya event SMA Negeri 1 Durenan CUP 2019. Selain adanya SMA Negeri 1 Durenan CUP 2019 ini event resmi PERBASI yakni PERBASI CUP dan Studend Basketball League. SMA Negeri 1 Durenan CUP 2019 adalah kompetisi basket terpopuler yang dikelola secara profesional oleh anak anak ekstra kulikuler SMAN 1 Durenan khususnya di Kabupaten Trenggalek yang diatur oleh Persatuan Bola Basket Seluruh Indonesia (PERBASI) dan diikuti oleh jenjang sekolah SMP/MTs diseluruh Karisidenan Kediri. Kompetisi ini dimulai pada tahun 2019 yang dicetuskan oleh beberapa anggota Ekstra Kulikuler bola basket anak anak SMAN 1 Durenan dan pembinanya pada saat itu. Pada tahun ini SMA Negeri 1 Durenan CUP 2019 telah dua

kali diselenggarakan yakni pada tahun 2018, 2019 akan tetapi event basket ini baru tahun ini dimunculkan.

Perlu diketahui perkembangan IPTEK yang maju prestasi dapat diperoleh melalui beberapa hal salah satunya memanfaatkan penelitian analisis data statistik pertandingan. Pada era ini penelitian analisis berbasis data pertandingan sangatlah populer. Analisis data statistik adalah proses mencari dan menyususn secara sistematis data yang diperoleh dari hasil wawancara, catatan lapangan, dan dokumentasi, dengan cara mengoraganisasikan data ke dalam kategori, menjabarkan ke dalam unit-unit, melakukan sintesa, menyusun ke dalam pola, memilih mana yang penting dan yang akan dipelajari, dan membuat kesimpulan sehingga mudah difahami oleh diri sendiri maupun orang lain (Sugiyono, 2012).

Analisis dalam penelitian jenis apapun, adalah merupakan cara berfikir. Hal itu berkaitan dengan pengujian secara sistematis terhadap sesuatu untuk menentukan bagian, hubungan antar bagian, dan hubungannya dengan keseluruhan. Analisis adalah untuk mencari pola (Sugiyono, 2012). Analisis adalah penguraian suatu persoalan atau permasalahan serta menjelaskan mengenai hubungnan antara bagian-bagian yang ada didalamnya untuk selanjutnya diperoleh suatu pengertian secara keseluruhan (Maith, 2013). Dapat disimpulkan bahwa analisis merupakan suatu proses mengorganisasikan dan mengurutkan suatu data atau informasi kedalam pola, kategori dan satuan uraian dasar sehingga dapat ditemukan tema dan dapat dirumuskan hipotesis.

Menurut (Irianto, 2013) Statistik adalah sekumpulan cara maupun aturanaturan yang berkaitan dengan pengumpulan, pengolahan (analisis), penarikan kesimpulan, atas data data yang berbentuk angka dengan menngunakan suatu asumsi asumsi tertentu. Adapun data statistik yang menunjukkan para pemain asli Indonesia pada ajang Indonesia Basketball League rerata poin tertinggi 11,78 poin per pertandingan (A. R. Pratama, 2018). Itupun berada di posisi ke dua puluh bersaing dengan para pemain 
Jurnal Kejaora: Jurnal Kesehatan Jasmani dan Olah Raga

ISSN: 2541-5042 (Online)

ISSN: 2503-2976 (Print)

Volume 5 Nomor 1, Edisi April 2020

asing yang bermain di Indonesia Basketball League.

Statistik ini menunjukkan bahwasanya perlu ada pengembangan bentuk latihan dan penyetaraan bentuk permainan dengan para pemain asing. Sampai saat ini menurut data statistik resmi Indonesia Basketball League 2018 pemain Indonesia yang memiliki rerata poin tersebut yakni Nuke Dwi Saputra. Sementara itu di urutan teratas ada nama andalan NSH Jakarta, Brachon Lanalt Griffin dengan 24,5 poin perlaga. Dibelakangnya ada David Seagers dengan 24,2 poin, dan pilar BSB Hangtuah, Keenan Thomas Palmore dengan 23,78 poin (Pratama, 2018).

Menggunakan statistik bisa menggambarkan dengan jelas bagaimana performa dari tim dalam setiap pertandingan. Dengan statistik dapat mengetahui kekurangan atau kesalahan tim serta bahan evaluasi saat tim bertanding. Hal ini yang sering dihiraukan oleh pelatih sehingga tidak bisa membaca kekurangan maupun kelebihan tim dari data statistik pertandingan dan hanya mengevaluasi kemampuan atlet berdasarkan apa yang dilihat selama pertandingan (Ramadhani \& Hariyanto, 2017).

Tujuan penelitian ini secara umum untuk mengetahui "Keterampilan Bermain tim putra bola basket SMP Negeri 2 Trenggalek pada SMA Negeri 1 Durenan Cup 2019", sedangkan tujuan secara khusus adalah untuk "menganalisis pertandingan tim putra bola basket SMP Negeri 2 Trenggalek pada SMA Negeri 1 Durenan Cup 2019".

\section{METODE}

Jenis penelitian ini adalah kuantitatif dimana menggunakan pendekatan statistik deskriptif kuantitatif yaitu bertujuan untuk mendeskripsikan (memaparkan) peristiwa pada masa kini. Deskripsi peristiwa tersebut dilakukan secara sistemik yang menekankan pada pengungkapan data berdasarkan fakta yang diperoleh dari lapangan (Winarno, 2013). Hal ini diperkuat oleh (Maksum, 2012) Penelitian Deskriptif adalah penelitian yang dilakukan untuk mengambarkan gejala, fenomena atau peristiwa tertentu. Pengumpulan data dilakukan untuk mendapatkan infromasi terkait dengan 


\begin{tabular}{|c|c|c|}
\hline & & $\begin{array}{l}\text { pepohonan masih banyak } \\
\text { tumbuh dan rindang. }\end{array}$ \\
\hline 2 & $\begin{array}{lr}\text { Sarana } & \text { Dan } \\
\text { Prasarana } & \text { Ekskul } \\
\text { Bola Basket } & \text { SMP } \\
\text { Negeri } & 2 \\
\text { Trenggalek } & \end{array}$ & $\begin{array}{l}\text { Cukup memamadai dan } \\
\text { lumayan lengkap tapi ada } \\
\text { beberapa sarpras modifikasi } \\
\text { dari pelatih. }\end{array}$ \\
\hline 3 & $\begin{array}{l}\text { Latihan Per Pekan } \\
\text { Untuk Tim Putra } \\
\text { Bola Basket SMP } \\
\text { Negeri } \\
\text { Trenggalek }\end{array}$ & $\begin{array}{l}3 \text { kali, yakni hari senin, } \\
\text { kamis, dan sabtu. }\end{array}$ \\
\hline 4 & $\begin{array}{lr}\text { Instrumen } & \\
\text { pengukur } & \text { hasil } \\
\text { latihan tim } & \text { bola } \\
\text { basket putra SMP } & \text { Negeri } \\
\text { Trenggalek } & 2 \\
\end{array}$ & $\begin{array}{lcc}\text { Ada } & \text { beberapa intrumen } \\
\text { yakni peningkatan } & \text { daya } \\
\text { tahan dan } & \text { buku } \\
\text { perkembangan atlet. } & \end{array}$ \\
\hline 5 & $\begin{array}{l}\text { Tingkat remangat } \\
\text { pemain saat } \\
\text { berlatih maupun uji } \\
\text { coba }\end{array}$ & $\begin{array}{l}\text { Para pemain memilik } \\
\text { semangat yang begitu baik, } \\
\text { hal itu terlihat walaupun } \\
\text { beberapa kali dibentak oleh } \\
\text { pelatih mereka tetap } \\
\text { tersenyum dan ada } \\
\text { keinginan terus mencoba, } \\
\text { bahkan ketika pelatih } \\
\text { berhalangan hadir tim in } \\
\text { tetap berlatih sendiri } \\
\text { mengulangi lagi teknik } \\
\text { teknik yang diajarkan pelath } \\
\text { pada pertemuan } \\
\text { sebelumnya di tempat } \\
\text { latihan. }\end{array}$ \\
\hline 6 & $\begin{array}{l}\text { Unit latihan per } \\
\text { pertemuan }\end{array}$ & $\begin{array}{l}5 \text { sampai } 6 \text { unit dan } \\
\text { beberapa teknik. }\end{array}$ \\
\hline 7 & $\begin{array}{l}\text { Jumlah Pemain } \\
\text { Yang Mengikuti } \\
\text { Ekskul Bola Basket } \\
\text { Putra }\end{array}$ & $\begin{array}{l}8 \text { orang sebelumnya } \\
\text { mencapai belasan orang } \\
\text { dikarenakan sudah kelas } 9 \\
\text { maka yang lainnya } \\
\text { dipersilahkan fokus pada } \\
\text { pelajaran. }\end{array}$ \\
\hline 8 & $\begin{array}{l}\text { Volume latihan per } \\
\text { pertemuan }\end{array}$ & Rendah, sedang, dan tinggi \\
\hline 9 & $\begin{array}{l}\text { Kerjasama pemain } \\
\text { dalam } \\
\text { mempersiapkan } \\
\text { segala sesuatu } \\
\text { sebelum latihan } \\
\text { dimulai }\end{array}$ & $\begin{array}{l}\text { Hal ini terlihat ketika pelatih } \\
\text { belum datang para pemain } \\
\text { sudah mengambil peralatan } \\
\text { yang diperlukan misal } \\
\text { mengambil bola, wadah } \\
\text { minum dll. }\end{array}$ \\
\hline 10 & \begin{tabular}{ll}
\multicolumn{2}{l}{ Tingkat } \\
\multicolumn{2}{l}{ kesenangan para } \\
pemain & dengan \\
program & latihan \\
yang ada &
\end{tabular} & $\begin{array}{l}\text { Ada yang terlihat senang } \\
\text { ada yang terlihat kurang hal } \\
\text { ini tergantung kondisi hat } \\
\text { pemain tersebut, tetapi lebih } \\
\text { banyak senangnya dengan } \\
\text { model model latihan baru } \\
\text { yang diterapkan pelatih. }\end{array}$ \\
\hline 11 & $\begin{array}{l}\text { Keinginan para } \\
\text { pemain untuk } \\
\text { mencoba } \\
\text { melakukan suatu } \\
\text { tekhnik maupun } \\
\text { strategi pada saat } \\
\text { latihan }\end{array}$ & $\begin{array}{l}\text { Mereka selalu } \\
\text { mempraktikkan apa yang } \\
\text { mereka dapat walaupun } \\
\text { mereka belum waktunya } \\
\text { mendapatkan giliran, } \\
\text { menunnggu giliran sambil } \\
\text { melatih dan memahami. }\end{array}$ \\
\hline 12 & $\begin{array}{l}\text { Kedisiplinan } \\
\text { Tingkat Latihan }\end{array}$ & $\begin{array}{l}\text { Saya lihat pada saat saya } \\
\text { beberapa kali mengamati } \\
\text { latihan mereka hampir tidak } \\
\text { ada yang terlambat. }\end{array}$ \\
\hline 13 & $\begin{array}{l}\text { Waktu Latihan } \\
\text { Berapa Jam Per } \\
\text { Pertemuan }\end{array}$ & $\begin{array}{l}\text { 3 jam yakni jam } 14.00 \text { ampai } \\
\text { jam } 17.00\end{array}$ \\
\hline
\end{tabular}

\begin{tabular}{|c|c|c|}
\hline 14 & $\begin{array}{l}\text { Waktu Latihan } \\
\text { Siang, Pagi, Atau } \\
\text { Sore }\end{array}$ & Sore \\
\hline 15 & $\begin{array}{l}\text { Latihan Ketika } \\
\text { Mendekati } \\
\text { Kompetisi Mulai } \\
\text { Waktunya, Jamnya } \\
\text { Dan Lain Lain } \\
\text { Kalau Ada }\end{array}$ & $\begin{array}{l}\text { Biasanya ada tambahan } \\
\text { latihan jika sudah mendekati } \\
\text { kompetisi seperti saat ini, di } \\
\text { hari minggu jamnya mulai } \\
\text { jam } 07.00 \text { sampai } 10.00 \text { dan } \\
\text { uji coba pada sore harinya. }\end{array}$ \\
\hline
\end{tabular}

\section{HASIL DAN PEMBAHASAN}

Hasil penelitian untuk kompetisi SMA Negeri 1 Durenan Cup 2019 ini karena jumlah pertandingan yang dipertandingkan oleh SMP Negeri 2 trenggalek mulai fase gugur hingga babak perebutan juara ke tiga, hanya ada tiga pertandingan maka yang di analisis dan di evaluasi sesuai jumlah pertandingan yang dipertandingkan. Analisis ini akan disimpulkan secara detail pada setiap indikator dalam statistik, adapun hasil penelitian sebagai berikut :

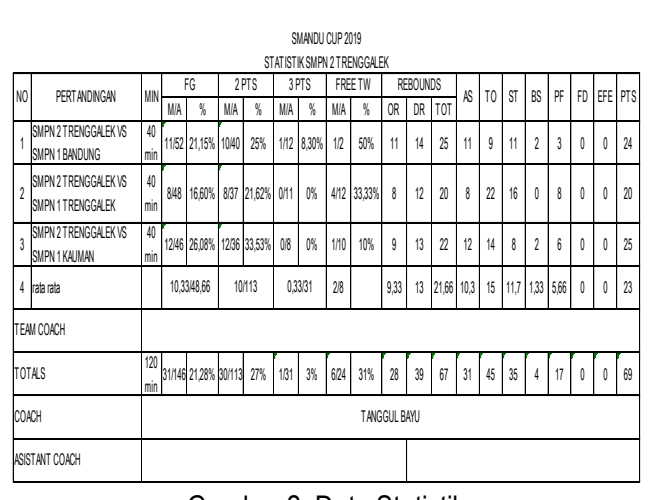

Gambar 2. Data Statistik

Dari gambar 2 penelitian statistik pertandingan dapat dijelaskan bahwa tim Putra Bola Basket SMP Negeri 2 Trenggalek melakukan pertandingan sebanyak tiga kali dengan rincian satu kali bertandingan di fase gugur, satu kali fase semifinal, satu kali fase semifinal dan satu kali perebutan juara ketiga.

Statistik pertandingan juga memperlihatkan persentase dari offense dan defense yang diperoleh tim atau individu selama pertandingan. Adapun indikator offense pada statistik terdiri dari field goals, 2 points, 3 points, free throw, offensive rebound, fast break points, second chance points, bench points dan points in the paint. Sementara defense terdiri dari defensive rebound, turn overs, steal, block, dan points from turn overs (Haqqi, 2016). 
Jurnal Kejaora: Jurnal Kesehatan Jasmani dan Olah Raga

ISSN: 2541-5042 (Online)

ISSN: 2503-2976 (Print)

Volume 5 Nomor 1, Edisi April 2020

1. Field goal

\begin{tabular}{|c|c|c|c|c|c|c|c|}
\hline \multirow{2}{*}{$\begin{array}{l}N \\
0\end{array}$} & \multirow{2}{*}{$\begin{array}{l}\text { Pertandi } \\
\text { ngan }\end{array}$} & \multicolumn{2}{|c|}{ FG \% } & \multicolumn{2}{|c|}{2 Point $\%$} & \multicolumn{2}{|c|}{$\begin{array}{l}3 \text { Point } \\
\%\end{array}$} \\
\hline & & $\mathrm{H}$ & $\mathrm{M} / \mathrm{A}$ & $\mathrm{H}$ & $M / A$ & $\mathrm{H}$ & $\begin{array}{c}\mathrm{M} / \\
\mathrm{A}\end{array}$ \\
\hline 1 & $\begin{array}{l}\text { SMPN } 2 \\
\text { Trenggal } \\
\text { ek Vs } \\
\text { SMPN } 1 \\
\text { Bandung }\end{array}$ & $\begin{array}{l}21 . \\
15\end{array}$ & $\begin{array}{c}11 / 5 \\
2\end{array}$ & 25 & $\begin{array}{c}10 / 4 \\
0\end{array}$ & $\begin{array}{l}8 . \\
3\end{array}$ & $\begin{array}{l}1 / \\
12\end{array}$ \\
\hline 2 & $\begin{array}{l}\text { SMPN } 2 \\
\text { Trenggal } \\
\text { ek Vs } \\
\text { SMPN } 1 \\
\text { Trenggal } \\
\text { ek }\end{array}$ & $\begin{array}{c}16 . \\
6\end{array}$ & $8 / 48$ & $\begin{array}{l}21 . \\
62\end{array}$ & $8 / 37$ & 0 & $\begin{array}{l}0 / \\
11\end{array}$ \\
\hline 3 & $\begin{array}{l}\text { SMPN } 2 \\
\text { Trenggal } \\
\text { ek Vs } \\
\text { SMPN } 1 \\
\text { Kauman }\end{array}$ & $\begin{array}{l}26 . \\
08\end{array}$ & $\begin{array}{c}12 / 4 \\
6\end{array}$ & $\begin{array}{l}33 . \\
33\end{array}$ & $\begin{array}{c}12 / 3 \\
6\end{array}$ & 0 & $\begin{array}{l}0 / \\
8\end{array}$ \\
\hline & $\begin{array}{l}\text { Rata } \\
\text { Iruh } \\
\text { andingan }\end{array}$ & $\begin{array}{l}21 . \\
28\end{array}$ & $\begin{array}{c}31 / 1 \\
46\end{array}$ & 27 & $\begin{array}{c}30 / 1 \\
13\end{array}$ & 3 & $\begin{array}{l}1 / \\
31\end{array}$ \\
\hline
\end{tabular}

Dari data penelitian statistik pertandingan SMPN 2 Trenggalek tim putra dari field goal mencapai $21.28 \%$ pada seluruh pertandingan dengan memasukan 31 bola dengan percobaan sebanyak 146 kali. Pada data 2 point dan 3 point sangat berbeda jauh, bisa dilihat pahwa persentasi 2 poin dari tim SMPN 2 Trenggalek tim putra pada SMA Negeri 2 Durenan Cup 2019 lebih dominan, dimana persentase 2 point berkisar $27 \%$ dengan memasukan 30 bola dari 113 percobaan dari seluruh pertandingan yang sudah dilalui tim tersebut.

Jika dilihat dari data penelitian sebelumnya dengan $\mathrm{KU}$ yang sama dari data penelitian KU 14 Jatim (Ramadhani \& Hariyanto, 2017), dengan field goal tertinggi digame ke-22 dengan $24,81 \%$ dan terendah digame ke-13 dan 17 dengan $12,40 \%$ dari total keseluruhan yang berhasil.

Data tim Sidoarjo (Fitriasmara, 2017) field goal melakukan 451 kali percobaan dan berhasil sebanyak 163 kali mencapai persentase (38\%), untuk 2 points melakukan percobaan sebanyak 335 kali dan berhasil sebanyak 142 kali mencapai persentase $(42 \%)$, untuk 3 points melakukan 116 kali percobaan dan hanya berhasil 21 kali mencapai persentase $(12 \%)$.

Dari analisis Field goal SMPN 2 Trenggalek masih jauh dari harapan yang diinginkan pelatih meskipun dari usia pemain pada subyek penelitian tidak jauh berbeda.

\section{Free Throw}

Tabel 3. Freethrow Persentase SMPN 2 Trenggalek

\begin{tabular}{clcc}
\hline \multirow{2}{*}{ No } & Pertandingan & \multicolumn{2}{c}{$\begin{array}{c}\text { Free Throw } \\
\text { \%ome }\end{array}$} \\
\cline { 3 - 4 } 1 & $\begin{array}{l}\text { SMPN 2 Trenggalek Vs SMPN 1 } \\
\text { Bomen }\end{array}$ & 50 & $1 / 2$ \\
\hline 2 & $\begin{array}{l}\text { Sandung 2 Trenggalek Vs SMPN 1 } \\
\text { Trenggalek }\end{array}$ & 33.33 & $4 / 12$ \\
\hline 3 & $\begin{array}{l}\text { SMPN 2 Trenggalek vs SMPN 1 } \\
\text { Kauman }\end{array}$ & 10 & $1 / 10$ \\
\hline & Rata Rata & 31 & $6 / 24$ \\
\hline
\end{tabular}

Data pada tabel 3 Tim Putra Bola Basket SMP Negeri 2 Trenggalek saat melakukan pertandingan di SMAN 2 Durenan Cup dari fase grup, semi final dan sampai pada perbutan juara 3 rata rata persentase Freethrow saat pertandingan ini berkisar $31 \%$ pada semua pertandingan dari 24 percobaan freetrhow hanya 6 bola yang masuk.

Pada data statistik KU 14 Jatim (Ramadhani \& Hariyanto, 2017) dapat diketahui free throw tertinggi digame ke-7 dengan $31,91 \%$ dan terendah digame ke-22 dan 32 dengan 8,51\%. Pada analisis data Tim Sidoarjo (Fitriasmara, 2017) statistik free throw melakukan sebanyak 73 kali dan berhasil sebanyak 33 kali mencapai persentase $(45 \%)$, dapat dilihat dari 3 data yang ada untuk statistik free throw SMPN 2 Trenggalek mendekati data yang sama dari 2 penelitian sebelumnya.

\section{Rebound}

Tabel 4. Rebound Statistik

\begin{tabular}{|c|c|c|c|c|c|c|c|c|}
\hline $\mathbf{N}$ & \multirow{2}{*}{\multicolumn{2}{|c|}{$\begin{array}{c}\text { Pertandinga } \\
n\end{array}$}} & \multicolumn{2}{|c|}{ OR } & \multicolumn{2}{|c|}{ DR } & \multicolumn{2}{|c|}{ TOT } \\
\hline 0 & & & $\mathrm{H}$ & $A$ & $\mathrm{H}$ & A & $\mathrm{H}$ & $A$ \\
\hline 1 & $\begin{array}{l}\text { SMPN } \\
\text { Trenggalek } \\
\text { Vs SMPN } \\
\text { Bandung }\end{array}$ & $\begin{array}{l}2 \\
1\end{array}$ & 11 & 9 & 14 & 19 & 25 & 19 \\
\hline 2 & $\begin{array}{l}\text { SMPN } \\
\text { Trenggalek } \\
\text { Vs SMPN } \\
\text { Trenggalek }\end{array}$ & $\begin{array}{l}2 \\
1\end{array}$ & 8 & 15 & 12 & 17 & 20 & 32 \\
\hline 3 & $\begin{array}{l}\text { SMPN } \\
\text { Trenggalek } \\
\text { Vs SMPN } \\
\text { Kauman }\end{array}$ & $\begin{array}{l}2 \\
1\end{array}$ & 9 & 13 & 13 & 14 & 22 & 27 \\
\hline
\end{tabular}

Pada statistik pertandingan dapat dijelaskan bahwa tim Putra Bola Basket SMP Negeri 2 Trenggalek saat melakukan pertandingan melawan SMP Negeri 1 Bandung di fase gugur, untuk total offensef 
Jurnal Kejaora: Jurnal Kesehatan Jasmani dan Olah Raga

ISSN: 2541-5042 (Online)

ISSN: 2503-2976 (Print)

Volume 5 Nomor 1, Edisi April 2020

rebounds (11), untuk deffensef rebounds total mencapai (14), untuk total rebounds mencapai (25), sementara SMP Negeri 1 Bandung total offensef rebounds mencapai (9), untuk deffensef rebounds mencapai (10), untuk total rebounds mencapai (19), maka bisa dilihat perbandingan total rebounds SMPN 2 Trenggalek mengungguli total rebounds SMP Negeri 1 Bandung, dan pada akhirnya SMP Negeri 2 Trenggalek lebih banyak memperoleh poin dan memenangkan pertandingan ini.

Data statistik KU 14 Jatim (Ramadhani \& Hariyanto, 2017) terkait offensive rebound terbaik digame ke-32 dengan $26,03 \%$ dan terendah digame ke- 22 dengan 10,96\%, deffensive rebound tertinggi digame ke-7 dengan $19,75 \%$ dan terendah digame ke-22 dengan $12,96 \%$. Sedangkan data statistik Tim sidoarjo (Fitriasmara, 2017) rebounds untuk ofensive rebounds sebanyak 95 kali sedangkan defensive rebound sebanyak 177 kali jadi total rebounds yang dilakukan sebanyak 272 kali. Sangat jauh perbandingannya dengan tim putra SMPN 2 Trenggalek dana event SMA Negeri 1 Cup 2019 ini bisa dipengaruhi dari segi fisik tiap pemain yang tidak sama.

\section{Assist}

\begin{tabular}{|c|c|c|c|}
\hline & & & \\
\hline \multirow[t]{2}{*}{ No } & \multirow[t]{2}{*}{ Pertandingan } & \multicolumn{2}{|c|}{ Assist } \\
\hline & & Home & Away \\
\hline 1 & $\begin{array}{l}\text { SMPN } 2 \text { Trenggalek } \\
\text { Vs SMPN } 1 \text { Bandung }\end{array}$ & 11 & 10 \\
\hline 2 & $\begin{array}{llr}\text { SMPN } & 2 \text { Trenggalek } \\
\text { Vs } & \text { SMPN } & 1 \\
\text { Trenggalek }\end{array}$ & 8 & 13 \\
\hline 3 & $\begin{array}{l}\text { SMPN } 2 \text { Trenggalek vs } \\
\text { SMPN } 1 \text { Kauman }\end{array}$ & 12 & 17 \\
\hline
\end{tabular}

Tim Putra Bola Basket SMP Negeri 2 Trenggalek saat melakukan pertandingan melawan SMP Negeri 1 Bandung di fase gugur, untuk total assist (11), sementara SMP Negeri 1 Bandung total assist mencapai (10), maka bisa dilihat perbandingan total assist SMP Negeri 2 Trenggalek mengungguli total assist SMP Negeri 1 Bandung, dan kita tahu bahwasanya total assist ini sangat berguna untuk menambah point tim guna memenangkan pertandingan maka daripada itu akhirnya point yang diperoleh oleh SMP

Negeri 2 Trenggalek lebih banyak dan memenangkan pertandingan ini.

Dari data KU 14 Jatim (Ramadhani \& Hariyanto, 2017) assist tertinggi digame ke$26,39 \%$ dan terendah digame ke-8,33\%. (Fitriasmara, 2017) untuk assist tim Sidoarjo sebanyak 63 kali dari seluruh pertandingan. Dari data statistik ini pun Assist yang dimiliki oleh tim Putra SMPN 2 Trenggalek tidak cukup tinggi bila dibandingkan dengan 2 data tersebut.

\section{Turnovers}

\begin{tabular}{clcc}
\multicolumn{4}{c}{ Tabel 6. Turnovers Statistik } \\
\hline No & \multicolumn{1}{c}{ Pertandingan } & \multicolumn{2}{c}{ Turnovers } \\
\cline { 3 - 4 } & & Home & Away \\
\hline 1 & SMPN 2 Trenggalek & 9 & 16 \\
& Vs SMPN 1 Bandung & & \\
\hline 2 & $\begin{array}{l}\text { SMPN 2 Trenggalek } \\
\text { Vs SMPN 1 }\end{array}$ & 22 & 6 \\
\hline & Trenggalek & & 13 \\
\hline 3 & $\begin{array}{l}\text { SMPN 2 Trenggalek } \\
\text { vs SMPN 1 Kauman }\end{array}$ & 14 & \\
\hline
\end{tabular}

Tim Putra Bola Basket SMP Negeri 2 Trenggalek saat melakukan pertandingan melawan SMP Negeri 1 Kauman di fase perebutan juara ke tiga, untuk total turnovers (14), sementara SMP Negeri 1 Kauman total turnovers mencapai (13), maka bisa dilihat perbandingan total turnovers SMP Negeri 1 Kauman sedikit mengungguli total turnovers SMP Negeri 2 Trenggalek, hal ini karena semakin sedikit turnovers maka dikatakan lebih unggul, dan kita tahu bahwasanya total turnovers ini sangat mempengaruhi dikarenakan turnovers termasuk kesalahan apabila kesalahan itu semakin tinggi maka kemungkinan untuk kalah semakin tinggi.

Dibandingkan dengan data statistik KU 14 Jatim (Ramadhani \& Hariyanto, 2017) turnover tertinggi digame ke-17 dengan $24,09 \%$ dan terendah digame ke-22 dengan 7,30\%. (Fitriasmara, 2017) Turnover tim Sidoarjo sebanyak 110 kali dari seluruh pertandingan. Dari 2 data ini data statistik Turnover dari tim putra SMPN 2 Trenggalek berjumlah total seluruh pertandingan 45 kali Turnovers jauh lebih baik dari data tim Sidoarjo. 
Jurnal Kejaora: Jurnal Kesehatan Jasmani dan Olah Raga

ISSN: 2541-5042 (Online)

ISSN: 2503-2976 (Print)

Volume 5 Nomor 1, Edisi April 2020

6. Steal

\begin{tabular}{clcc}
\multicolumn{4}{c}{ Tabel 7. Steal Statistik } \\
\hline No & \multicolumn{1}{c}{ Pertandingan } & \multicolumn{2}{c}{ Steal } \\
\cline { 3 - 4 } & & Home & Away \\
\hline 1 & $\begin{array}{l}\text { SMPN 2 Trenggalek } \\
\text { Vs SMPN 1 Bandung }\end{array}$ & 11 & 6 \\
\hline 2 & $\begin{array}{l}\text { SMPN 2 Trenggalek } \\
\text { Vs SMPN 1 }\end{array}$ & 16 & 18 \\
\hline & Trenggalek & & \\
\hline 3 & $\begin{array}{l}\text { SMPN 2 Trenggalek } \\
\text { vs SMPN 1 Kauman }\end{array}$ & 8 & 18 \\
\hline
\end{tabular}

Statistik pertandingan dapat dijelaskan bahwa tim Putra Bola Basket SMP Negeri 2 Trenggalek saat melakukan pertandingan melawan SMP Negeri 1 Bandung di fase gugur, untuk total steal (11), sementara SMP Negeri 1 Bandung total steal mencapai (6), maka bisa dilihat perbandingan total assist SMP Negeri 2 Trenggalek mengungguli total steal SMP Negeri 1 Bandung, dan kita tahu bahwasanya total steal ini sangat berguna untuk merebut bola lawan guna memenangkan pertandingan maka daripada itu akhirnya point yang diperoleh oleh SMP Negeri 2 Trenggalek lebih banyak dan memenangkan pertandingan ini.

KU 14 Jatim (Ramadhani \& Hariyanto, 2017) di peroleh data statistik steal terbanyak digame ke-29 dengan $23,91 \%$ dan terendah digame ke-13 dengan $9,78 \%$. Sedangkan dari data Tim Sidoarjo (Fitriasmara, 2017) diperoleh data Steal sebanyak 66 kali. Sedangkan data statistik tim Putra SMPN 2 Trenggalek adalah 45 kali melakukan Steal ini masih jauh jika dibandingkan dari 2 tim tersebut.

\section{Blocks}

\begin{tabular}{clcc}
\multicolumn{4}{c}{ Tabel 8. Blocks Statistik } \\
\hline No & \multicolumn{1}{c}{ Pertandingan } & \multicolumn{2}{c}{ Blocks } \\
\cline { 3 - 4 } & & Home & Away \\
\hline 1 & $\begin{array}{l}\text { SMPN 2 Trenggalek } \\
\text { Vs SMPN 1 Bandung }\end{array}$ & 2 & 2 \\
\hline 2 & $\begin{array}{l}\text { SMPN 2 Trenggalek } \\
\text { Vs SMPN 1 }\end{array}$ & 0 & 3 \\
\hline & Trenggalek \\
\hline 3 & $\begin{array}{l}\text { SMPN 2 Trenggalek } \\
\text { Vs SMPN 1 Kauman }\end{array}$ & 2 & 2 \\
\hline
\end{tabular}

Statistik pertandingan dapat dijelaskan juga bahwa tim Putra Bola Basket SMP Negeri 2 Trenggalek saat melakukan pertandingan melawan SMP Negeri 1 Kauman di fase perebutan juara ke tiga, untuk total blocks (2), sementara SMP Negeri
1 Kauman total blocks mencapai (2), maka bisa dilihat perbandingan total blocks SMP Negeri 2 Trenggalek sama dengan total blocks SMP Negeri 1 Kauman, dan kita tahu bahwasanya total blocks ini sangat berguna menggagalkan bola masuk ke ring dari serangan lawan guna memenangkan pertandingan maka daripada itu akhirnya point yang diperoleh oleh SMP Negeri 1 Kauman lebih banyak dan memenangkan pertandingan ini.

Data statistik KU 14 Jatim (Ramadhani \& Hariyanto, 2017) data blocked shoot tertinggi digame ke-29 dengan $22,22 \%$ dan terendah digame ke-7 dan 17 dengan $11,11 \%$. Tim Sidoarjo (Fitriasmara, 2017) data Block dilakukan sebanyak 9 kali. Sedangkan tim SMPN 2 Trenggalek statistik Block Shoot sangat rendah dilakukan sebanyak 4 kali dari seluruh pertandingan yang diikuti dan dikatakan sangat kurang dalam melakukan block shoot pada pertandingan yang dimainkan.

8. Fouls

\begin{tabular}{|c|c|c|c|}
\hline \multirow{3}{*}{ No } & \multicolumn{3}{|c|}{ Tabel 8. Fouls Statistik } \\
\hline & \multirow[t]{2}{*}{ Pertandingan } & \multicolumn{2}{|c|}{ Fouls } \\
\hline & & Home & Away \\
\hline 1 & $\begin{array}{l}\text { SMPN } 2 \text { Trenggalek } \\
\text { Vs SMPN } 1 \text { Bandung }\end{array}$ & 3 & 6 \\
\hline 2 & $\begin{array}{l}\text { SMPN } 2 \text { Trenggalek } \\
\text { Vs SMPN } 1 \\
\text { Trenggalek }\end{array}$ & 8 & 10 \\
\hline 3 & $\begin{array}{l}\text { SMPN } 2 \text { Trenggalek } \\
\text { vs SMPN } 1 \text { Kauman }\end{array}$ & 6 & 9 \\
\hline
\end{tabular}

Statistik pertandingan dapat dijelaskan bahwa tim Putra Bola Basket SMP Negeri 2 Trenggalek saat melakukan pertandingan melawan SMP Negeri 1 Bandung di fase gugur, untuk total fouls (3), sementara SMP Negeri 1 Bandung total fouls mencapai (6), maka bisa dilihat perbandingan total fouls SMP Negeri 2 Trenggalek lebih rendah daripada total fouls SMP Negeri 1 Bandung, dan kita tahu bahwasanya total fouls ini sangat mempengaruhi dikarenakan fouls termasuk kesalahan apabila kesalahan itu semakin tinggi maka kemungkinan untuk kalah semakin tinggi.

Dilihat dari data KU 14 Jatim (Ramadhani \& Hariyanto, 2017) data personal fouls terendah digame ke-22 dengan $7,21 \%$ dan tertinggi digame ke-7 
Jurnal Kejaora: Jurnal Kesehatan Jasmani dan Olah Raga

ISSN: 2541-5042 (Online)

ISSN: 2503-2976 (Print)

Volume 5 Nomor 1, Edisi April 2020

dengan $23,42 \%$, foul drawn tertinggi digame ke-7 dengan $28,57 \%$ dan terendah digame ke-22 dengan 5,49\%. Sedangkan tim Sidoarjo (Fitriasmara, 2017) data personal foul sebanyak 72 kali. Personal fouls yang dilakukan oleh SMPN 2 Trenggalek pada seluruh bertandingan dilakukan sebanyak 17 kali, bisa dikatakan semakin sedikit fouls maka semakin baik tim itu dalam suatu permainan dalam hal ini jika dibandingkan dari 2 data tim yang ada bahwa SMPN 2 Trenggalek masih lebih baik pada data statistik foulnya.

\section{KESIMPULAN}

Berdasarkan hasil penelitian mengenai analisis tim putra bola basket SMP Negeri 2 Trenggalek pada event SMA Negeri 1 Durenan Cup 2019 berdasarkan data yang diambil peneliti yang telah dipaparkan bahwasanya adanya cara untuk mengetahui statistik yang dapat dipergunakan oleh pelatih guna membuat program latihan kedepaannya komponen statistik yang paling berpengaruh pada pertandingan bola basket yaitu diurutkan mulai dari field goal dengan kategori baik, free throw dengan kategori kurang, rebound dengan kategori baik, steal dengan kategori baik, turnovers dengan kategori baik, assist dengan kategori baik, dan foul dengan kategori baik, Block dengan kategori baik. Karena dari 8 komponen tersebut dapat ditentukannya apa saja yang perlu diperbaiki dan dipertahankan oleh tim SMP Negeri 2 Trenggalek. Begitu juga Kurang maksimalnya Tim SMP Negeri 2 Trenggalek dalam turnamen ini yakni disebabkan oleh faktor kelelahan karena pada turnamen ini mereka hanya mempunyai sedikit pemain yakni antara 7-8 pemain saja.

\section{DAFTAR PUSTAKA}

Arikunto, S. (2014). Prosedur Penelitian (Suatu Pendekatan Praktik) (4th ed.). Jakarta: Rineke Cipta.

FIBA. (2018). Awwaba Peraturan resmi Bola Basket 2018.

Fitriasmara, D. (2017). Analisis Keunggulan tim Putra Bola Basket Sidoarjo pada Porprov Jawa Timur 2015 ( Berdasarkan Analisis Statistik

Pertandingan ). E Jurnal Prestasi Olahraga, 2(1).

Hapsari, A., Pratiknyo, E., \& Hidayah, T. (2013). Status Keterampilan Bermain Bolabasket Pada Club NBC ( Ngaliyan Basketball Center ). Journal of SPort Sciences and Fitness, 2(1), 6-10.

Haqqi, R. (2016). Analisis Pertandingan PerGame Dan Statistik Pertandingan Pada IBL (Indonesian Basketball League) Series III Yogyakarta 2016. Universitas Negeri Yogyakarta.

Irianto, A. (2013). Statistik: Konsep Dasar, Aplikasi, dan Pengembangannya (2nd ed.). Jakarta: Prenada Media.

Maith, H. A. (2013). Analisis Laporan Keuangan Dalam Mengukur Kinerja Keuangan Pada PT. Hanjaya Mandala Sampoerna TBK. Jurnal EMBA, 1(3), 619-628.

Maksum, A. (2012). Metodologi Penelitian dalam Olahraga (1st ed.). Surabaya: Unesa University Press.

Nurrochmah, S. dkk. (2009). Pengembangan Intrumen Tes Bola Basket Bagi Pemula. Jakarta: Deputi IPTEK Olahraga.

Pratama, A. R. (2018, April). Statistik Rata Rata Poin Pemain Basket IBL. Detik Sport.

Pratama, H. G. (2017). Pengaruh Power Tungkai Dan kekuatan LengahTerhadap kemampuan Standing Jump Shoot dan Quick Jump Shoot. Pendidikan Dewantara, 2(2), 127-140.

Ramadhani, F. R., \& Hariyanto, A. (2017). Analisis Kemampuan Teknik Bermain KU 14 Bola Basket dalam Kejuaraan Nasional 2017 Di jakarta Berdasarkan Data Statistik. Jurnal Prestasi Olahraga, 3(1), 1-11.

Ridjal, A. I. (2016). Perbandingan Kekuatan Otot Tungkai Antara Normal Foot dan Flat Foot Pada Atlet Basket. Universitas Hasanuddin Makasar.

Sodikun, I. (1992). Olahraga Pilihan Bola basket. Jakarta: Depdikbud.

Sugiyono. (2013). Metode Penelitian Kuantitatif, Kualitatif dan R\&D (19th ed.). Bandung: Alfabeta. 
Jurnal Kejaora: Jurnal Kesehatan Jasmani dan Olah Raga

ISSN: 2541-5042 (Online)

ISSN: 2503-2976 (Print)

Volume 5 Nomor 1, Edisi April 2020

Winarno, M. E. (2013). Metodologi Penelitian dalam Pendidikan Jasmani (2013th ed.). Malang: UM Press. 